\title{
Preventive Activity of Ginger (Zingiber officinale) Against Myelotoxicity and Hepatotoxicity Induced by Cyclohexatriene and Identification of the Most Active Compounds by GC-MS
}

\author{
K. Otmanine, ${ }^{a},{ }^{*}$ S. Hanini, ${ }^{b}$ O. Benkortbi, ${ }^{b}$ R. Bekri, ${ }^{c}$ K. Amroun, ${ }^{d}$ \\ M. Djellal, ${ }^{\text {S. Kohli, and K. Oumouna-Benachour }}{ }^{\mathrm{a}}$ \\ a Bioressources Naturelles Locales (LBRN) Laboratory, Hassiba Benbouali University of Chlef, \\ Faculty of Technology Department of Process Engineering, 02000 Chlef, Algeria \\ b Biomaterials and Transport Phenomena Laboratory (LBMPT), Yahia Fares University, \\ Department of Chemical Engineering and Environment, Médéa, 26000 , Algeria \\ c Laboratory of Haematology, Mohamed Boudiaf Hospital, Médéa, Algeria \\ d Laboratory of Pathological Anatomy, Mohamed Boudiaf Hospital, Médéa, Algeria \\ e Biomaterials and Transport Phenomena Laboratory (LBMPT), Equipe Biologie et \\ Pharmacologie Experimentale, Yahia Fares University, Department of Nature and Life \\ Sciences, Faculty of Sciences, Médéa, 26 000, Algeria
}

\begin{abstract}
This study aimed to uncover the preventive capability of Zingiber officinale against myelotoxicity, leukaemia, and hepatotoxicity. For the most part, this work depended on the subcutaneous injection of cyclohexatriene in rabbits to cause the illness by a synthetic strategy. In parallel, another group of rabbits was exposed to the injection of cyclohexatriene under similar conditions with the feeding Zingiber officinale, where it was discovered that the cyclohexatriene-induced myelotoxicity was counteracted. The histological examination additionally uncovered the hepato-defensive intensity of Zingiber officinale. The most pharmacologically active molecules of Zingiber officinale were recognised by gas chromatography-mass spectrometry (GC-MS).
\end{abstract}

\section{Keywords}

Zingiber officinale, hepato-protective activity, cyclohexatriene, myelotoxicity, GC-MS

\section{Introduction}

Nowadays, the main treatment for leukaemia is chemotherapy. This treatment is dangerous as much as it is effective, because alkylating antineoplastic agents target cancer cells and healthy cells at the same time. ${ }^{1}$ In addition, chemotherapy causes marrow depression, hence the risk of bacterial and viral infections.

Phytochemicals have been shown to possess anticarcinogenic and antimutagenic properties; thus, they can play an important role in lowering different types of neoplasia. ${ }^{2}$ Natural and dietetic nutraceuticals may possess anticancer activities, such as carotenoids which promote gap-junctional communication, in vitro, through the amplification of "connexin 43", or flavonoids, which modulate xenobiotic detoxification in phase I and II, or vitamin E which inhibits protein kinase $C$, an essential enzyme in tumour progression of certain types of cancer. ${ }^{3}$

In another clinical study on Chinese herbs, ginger was significantly associated with longer survival time of patients suffering from metastatic breast cancer. ${ }^{2}$ Numerous reports indicate that phytochemicals (e.g., cumin, red pepper, and ginger) can potentially prevent cancer by suppressing the

* Corresponding author: Khaled Otmanine

Email: otmaninegpp@gmail.com nuclear transcription factor- $\mathrm{B}(\mathrm{NF}-\kappa \mathrm{B})$ pathway that correlates with cancer and many inflammatory diseases. ${ }^{3}$

This research represents continuation of the research from the work published in 2017. Our research aims to elucidate a natural treatment based on Zingiber officinale by maintaining the molecular compatibility present in the plant to eliminate or reduce the side effects. Therefore, the therapeutic potential of Zingiber officinale was tested to prevent or cure myelotoxicity or leukaemia, as well as leave the marrow intact. Dominant research is based on in vitro tests. ${ }^{4,5,6}$ The purpose of all such research was to cause apoptosis in malignant cells by Zingiber officinale. This work attempted to accomplish an in vivo test in order to demonstrate that the pharmacological activity is quite different from that of an in vitro test.

\section{Materials and methods}

\subsection{Animal materials}

Rabbits were kindly supplied by the Laboratory of Pharmacotoxicology, Saidal Antibiotical of Médéa, Algeria. An albino race hybrid between New Zealanders and California - the mass of one rabbit was $1.5 \mathrm{~kg}$. Three male rabbits in each group. Age of rabbits: 6 to 7 months. 
Lot (1): Negative control, without treatment.

Lot (2): Zingiber officinale group. These rabbits were used to study the influence of the chronic consumption of Zingiber officinale (Gavage).

Lot (3): Positive control. Rabbits, singled out to cause bone marrow toxicity and/or leukaemia, by subcutaneously injecting $0.2 \mathrm{ml} \mathrm{kg}^{-1}$ of cyclohexatriene, three times a week.

Lot (4): Cyclohexatriene + Zingiber officinale. The consumption of Zingiber officinale by mouth at the same time with subcutaneous injection of $0.2 \mathrm{ml} \mathrm{kg}^{-1}$ cyclohexatriene three times a week.

Blood cells interval of New Zealand rabbit were: red blood cells (RBC) $4.5-7.0 \cdot 10^{6} / \mathrm{mm}^{3}$, white blood cells (WBC) $5-12 \cdot 10^{3} / \mathrm{mm}^{3}$, and platelet (PLA) $250-750 \cdot 10^{3} / \mathrm{mm}^{3}$.

\subsection{Plant materials}

Used was the natural extract of Zingiber officinale (imported from China) taken from fresh rhizome by a mechanical method, and dried form of Zingiber officinale. The same doses were administered to Lot (2) Zingiber officinale, and Lot (4) cyclohexatriene + Zingiber officinale, during the experiment.

\subsection{Gas chromatography-mass spectrometry (GC-MS)}

This analysis is a quality control aimed to determine the most pharmacologically active compounds. In order to extract Zingiber officinale oil from the dried Zingiber officinale rhizome, acetone was used as the extraction solvent by maceration method. The analysis was carried out at the Laboratory of the Scientific Police of Algiers. Apparatus: GC-MS model CLARUS 500 brand Perkin-Elmer.

\subsection{GC-MS method}

The experimental conditions of the GC-MS system were as follows: standard non-polar column TR 5-MS capillary, dimension: $30 \mathrm{Mts}$, ID: $0.25 \mathrm{~mm}$, film thickness: $0.25 \mu \mathrm{m}$. Flow of the mobile phase (carrier gas: He) was adjusted to

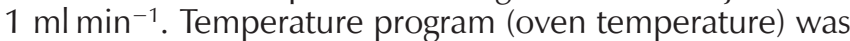
raised from $40{ }^{\circ} \mathrm{C}$ to $220{ }^{\circ} \mathrm{C}$ at $4{ }^{\circ} \mathrm{C} \mathrm{min}-1$, and the injection volume was $1 \mu \mathrm{l}$. Samples were run fully at a range of 20 and $550 \mathrm{~m} / \mathrm{z}$, and the results were compared using the Wiley and NIST Spectral Library Search Programme.

\subsection{Histology and histological stain (liver)}

The tissue was fixed with $10 \%$ formalin, dehydrated in successive alcohol baths at increasing concentrations $70 \%$ - $95 \%-100 \%$, and making of paraffin blocks using inclusion cassettes, then stored at $+4{ }^{\circ} \mathrm{C}$ for $24 \mathrm{~h}$, according to two studies..$^{8,9}$ Cutting ribbons were produced by using the microtome (type 820 Rotary Microtome) set at $4 \mathrm{mi}-$ crons. Tissue was deparaffinised by hydration of the slides in a battery containing: 2 toluene baths, 3 alcohol baths at decreasing concentration: $100 \%-95 \%-70 \%, 1$ bath of distilled water. Finally, the tissues were stained with hematoxylin and eosin stain (H\&E stain). ${ }^{8,9}$

\subsection{Statistical analysis}

Statistical analysis was performed using STATISTICA software, version 10.0.1 (STATISTICA Inc, LBMPT, Médéa, Algeria) for Windows. Data were analysed and presented as means \pm SD. Differences between continuous data were analysed using one-way ANOVA. $P<0.05$ was considered significant.

\section{Results and discussion}

\subsection{Haematological behaviour during one year}

The collection of blood was taken from the marginal ear vein of the rabbit. The blood was then put into EDTA tubes, and the Automatic Hematology Analyser (ERMA PCE210) at the Hematology Laboratory, Hospital of Médéa, was used for the analysis, which automatically gave CBC (complete blood count).

The analysis was carried out every 61 days.

\subsubsection{Interpretation}

The positive control Lot (3): made a leukocyte fall from the first three months. These values continued to fall significantly $(P<0.005)$ compared to the negative control Lot (1), until they had a severe leukopenia by the end of the experiment (Figs. 1(A) and 1(D)). The number of leukocytes fell below $2500 / \mathrm{mm}^{3}$ for the positive control Lot (3). These values fell below the limit of healthy rabbits $\left(5-12 \cdot 10^{3} / \mathrm{mm}^{3}\right) .^{7}$ These values continued to fall until the end of the experiment, when a slight increase was noticed (Figs. 1(A) and 1(D)), indicating that the cyclohexatriene had affected the cell precursors.

The dominant side effect of the cyclohexatriene is myelotoxicity. This can harm the bone marrow, leading to anaemia and leucopoenia. Animals with aplastic anaemia often develop myelodysplasia, leading in general to acute myeloid leukaemia. ${ }^{8}$

It is essential to understand the metabolism of cyclohexatriene, in order to determine the mechanisms of toxicity. The metabolism of cyclohexatriene occurs mainly in the liver, although metabolism in the bone marrow is believed to play a crucial role in the myelotoxicity of cyclohexatriene, because bone marrow is rich in peroxidase activity. It is likely that oxidative stress contributes to the toxicity of cyclohexatriene in a way that the initial metabolic step is the oxidation of cyclohexatriene to an epoxide (i.e., $\mathrm{d}$. cyclohexatriene oxide), which is catalysed primarily by CYP2E1 liver. ${ }^{8}$

For Lot (4) cyclohexatriene + Zingiber officinale, it was observed that rabbits surmount the action of cyclohexatriene, 
WBC

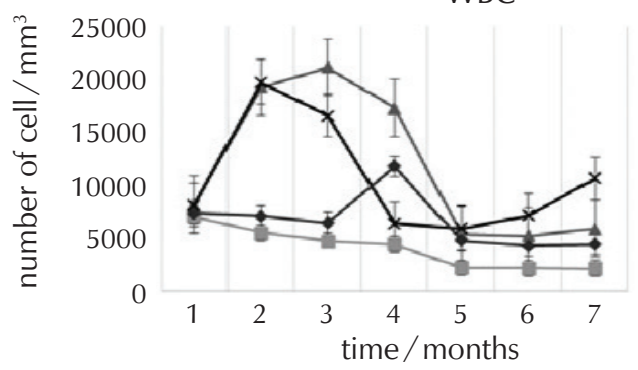

PLA

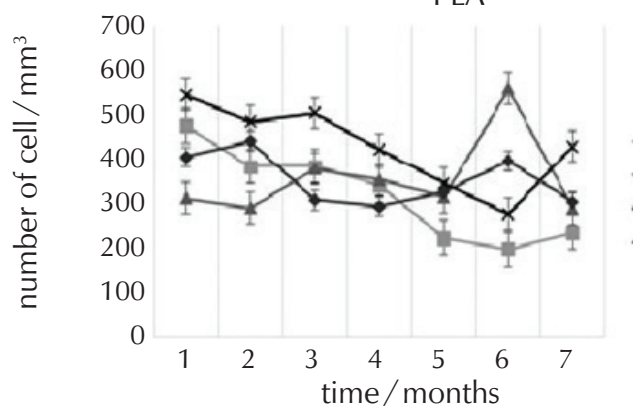

(A)

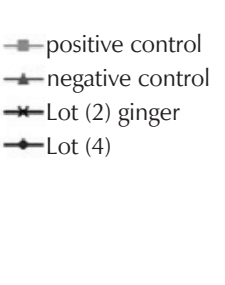

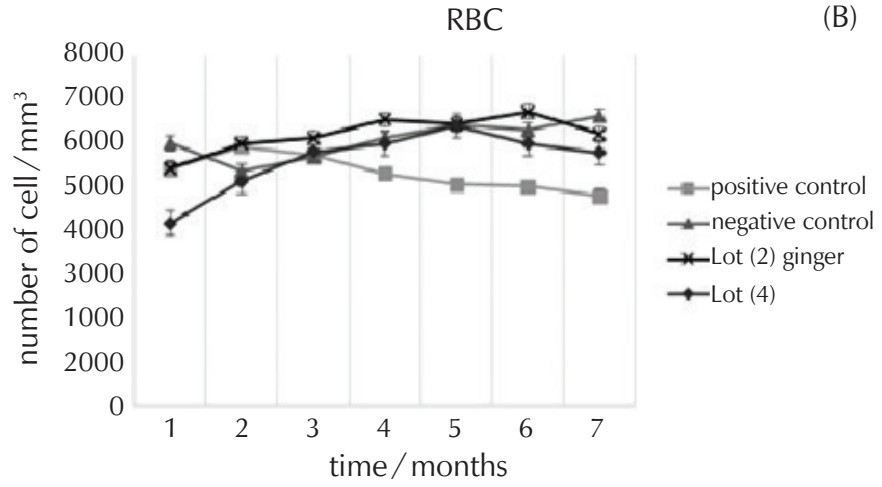

WBC

(D)

- - positive control

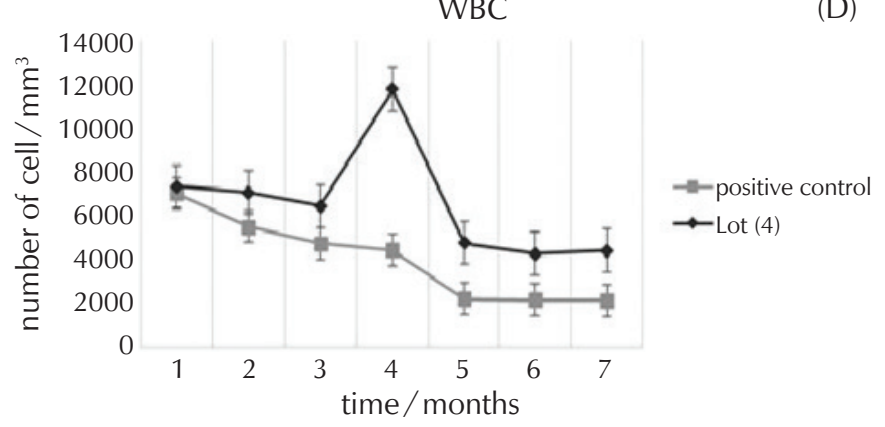

WBC

(E)

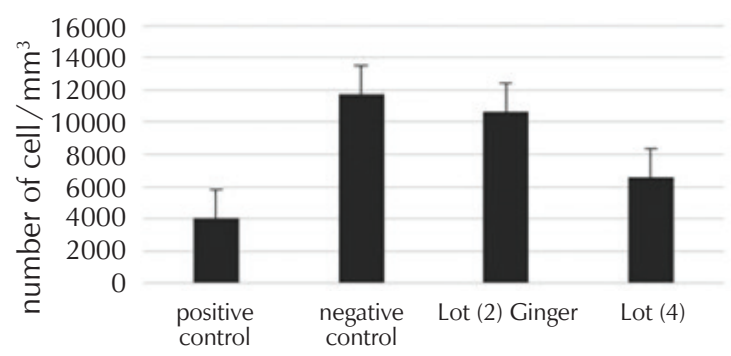

Fig. 1 - (A) Curve representing the kinetics of white blood cells during the experiment. (B) Curve representing the kinetics of red blood cells during the experiment. (C) Curve representing the kinetics of platelet during the experiment. (D) Curve representing the kinetics of white blood cells during the experiment (positive control and Lot (4)). (E) Histogram represents the average level of white blood cells during the experiment.

as cellular parameters of blood were kept in the rabbits' hygienic interval, and we can save this resistance from the initial 3 months, so ginger thwarted myelotoxicity of cyclohexatriene in spite of the low portion administrated in this period hundredth $L D_{0}$ of the natural extract $(1 / 100$ $\mathrm{LD}_{0}$ : Adaptation of rabbits). ${ }^{10}$

N.B.: $\mathrm{LD}_{0}$ (NOAEL) No Observed Adverse Effect Level is the most elevated portion that causes no lethality and no mortality. ${ }^{7}$ It is $75 \mathrm{~g} \mathrm{~kg}^{-1}$ of fresh rhizome and $7.5 \mathrm{~g} \mathrm{~kg}^{-1}$ of powdered Zingiber officinale. ${ }^{11}(1 / x) L_{0}$ : in order to find the lower dose that gives the best activity. ${ }^{10}$

In the next three months in which the rabbits received a high portion of ginger, $1 / 35 L_{0}$ of the natural extract (study of the preventive impact), it was observed that the amount of leukocytes (WBC) increased significantly $(P<0.005)$, indicating a safe upgrade prompted by ginger (Figs. 1(A) and $1(\mathrm{D})$ ).
From that point forward, it was attempted to lower the portion of ginger to $1 / 70 \mathrm{LD}_{0}$ (natural extract) for three months, with the end goal to discover the connection between dose and activity accountable for the decline in leukocytes. However, the values failed to exceed the lower furthest reaches of the hygienic interval. ${ }^{10}$

From there on, the two forms of ginger (fresh natural extract + powder) were combined in a portion of $1 / 35 L_{0}$, allowing for the synergistic impact of the two plant forms, where the blood parameters were settled in the rabbits' hygienic interval. ${ }^{10}$

For negative control (Lot (1)) and Zingiber officinale group (Lot (2)) (Fig. 1(A)), a relatively indistinguishable leukocyte improvement was observed, indicating that ginger, in various dosages, had no haematological unsettling influence, on the first supposition that ginger action occurs particularly within the sight of myelotoxicity. ${ }^{10}$ 


\subsection{Evaluation of the blood smear after bone marrow depression (positive control Lot (3)), and cyclohexatriene + Zingiber officinale group, Lot (4)}

Morphological perception of polynuclear neutrophils (PNN) in all rabbits of this group, Lot (3), demonstrates a hyper poisonous granulation (Figs. 2(A) and 2(B)). This indication affirms that cyclohexatriene influenced the bone marrow by practicing its mutagenic impact and, along these lines, we recorded serious pancytopenia (3 lined falling WBC, RBC, PLA). This cell fall takes esteems underneath the lower interval value (Figs. 1(A), 1(B), and 1(C)). We noticed that the group injected with cyclohexatriene and subjected to a ginger gavage, Lot (4), reveals cell morphology flawless and non-pathogenic, in light of the fact that there is no indication of intoxication (Figs. 1(A), 1(D), and $1(\mathrm{E})$ ) and (Figs. 2(C) and 2(D)). It should be pointed out that the $1 / 35 \mathrm{DL}_{0}$ from the ginger natural extract improved the best opposition to cyclohexatriene-instigated cell fall. ${ }^{10}$

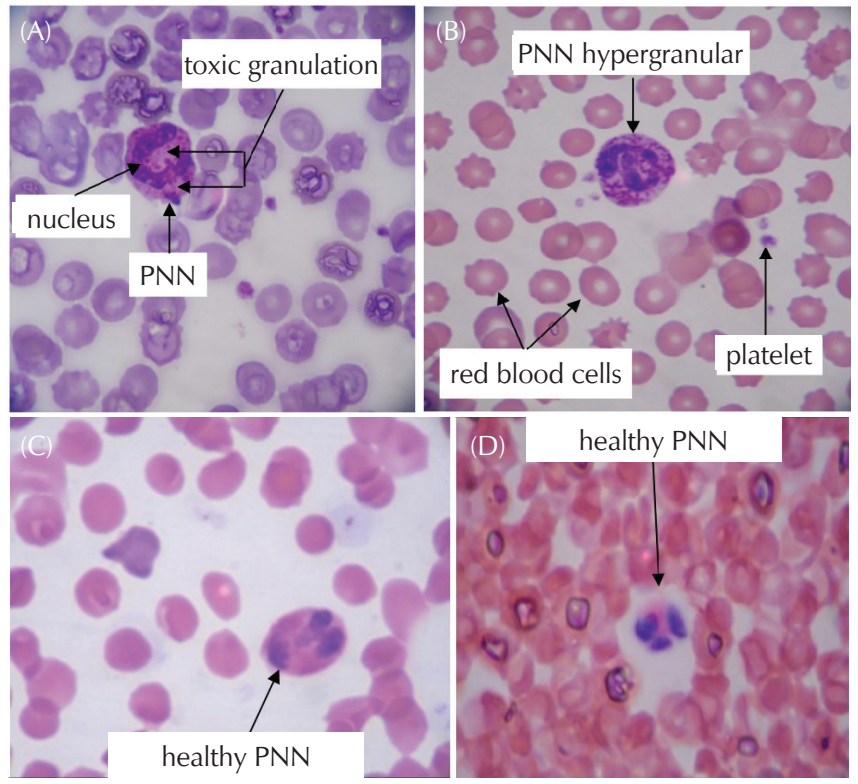

Fig. $2-(\mathrm{A})$ and (B): Blood smear observed by optical microscopy, Lot (3) positive control $(\times 100)$. (C) and (D): Blood smear shows healthy cells, Lot $(2)$ ginger $(\times 100) .{ }^{10}$

\subsubsection{Perception of medullary gram after bone marrow injury}

With the end goal to affirm the bone marrow injury, it is important to prepare the marrow smear. The specimen was taken using a sterile trocar by entering the iliac bone. At that point, the marrow was taken with a normal syringe (Fig. 3(E)). The smear demonstrates the morphology of the bone marrow antecedent cells. ${ }^{10}$

\subsubsection{Interpretation}

There was a hypertoxic granulation in the rabbits' marrow smears (positive control Lot (3)) (Figs. 3(A), 3(C), and 3(D)), and additionally, the observation of myelodysplasia phe- nomena (Fig. 3(D)). Knowing these indications of myelodysplasia regularly precede development of leukaemia. ${ }^{12,13,14}$ A few rabbits from the positive control Lot (3) had exceptionally poor marrow as a result of extreme bone marrow injury (Fig. 3(B)). Later, all animals from the positive control passed on following extreme pancytopenia, even before affirming the accomplishment of rabbits' leukaemia. However, the analysis revealed the dominance of acute leukaemia, which frequently showed as pancytopenia, ${ }^{15}$ because all the rabbits of positive control Lot (3) had died. ${ }^{10}$
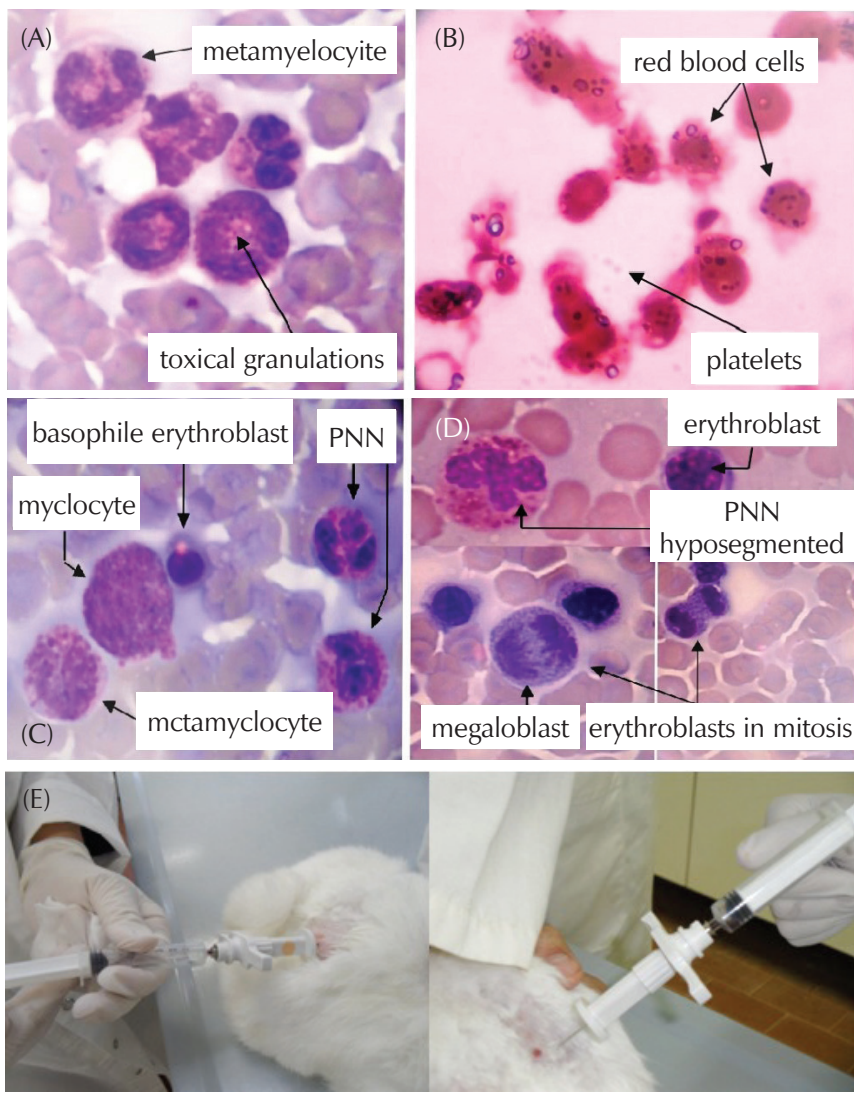

Fig. 3 - (A) Marrow smear: hyper toxic granulation Lot (3) Positive control. (B) Marrow smear: weak medullar smear in some rabbits Lot (3) positive control. (C) Marrow smear: hyper toxic granulation Lot (3) positive control. (D) Marrow smear: sign of myelodysplasia Lot (3) positive control. (E) Marrow sampling technique. ${ }^{10}$

\subsection{Anatomy investigation of tissue (dissection)}

\subsubsection{Liver}

The microscope revealed a normal liver parenchyma in negative control Lot (1) (Fig. 4(A)). In the group submitted to chronic gavage of ginger Lot (2): the hepatic parenchyma showed a normal appearance, without injury (Fig. 4(B)). In rabbits exposed to injection of cyclohexatriene (positive control Lot (3)), there was a cytoplasmic cell elucidation, with poisonous granulation in the whole specimen. These indications of inebriation affirm the hepatotoxic activity of cyclohexatriene (Figs. 4(C) and 4(D)). It might flag the nonappearance of tumour invasion. 
Concerning the gavage of Zingiber officinale and injection of cyclohexatriene in parallel, a heterogeneous appearance can be seen because of ordinary liver cells, healthy in their greater part, and a few cells with cytoplasmic granulations and elucidation (Figs. 4(E)). In this way, the progressions and cell harm instigated by cyclohexatriene in positive control Lot (3), were fundamentally diminished in the Lot (4) by the accompanying activity of Zingiber officinale, subsequently the term hepato-defensive ginger.
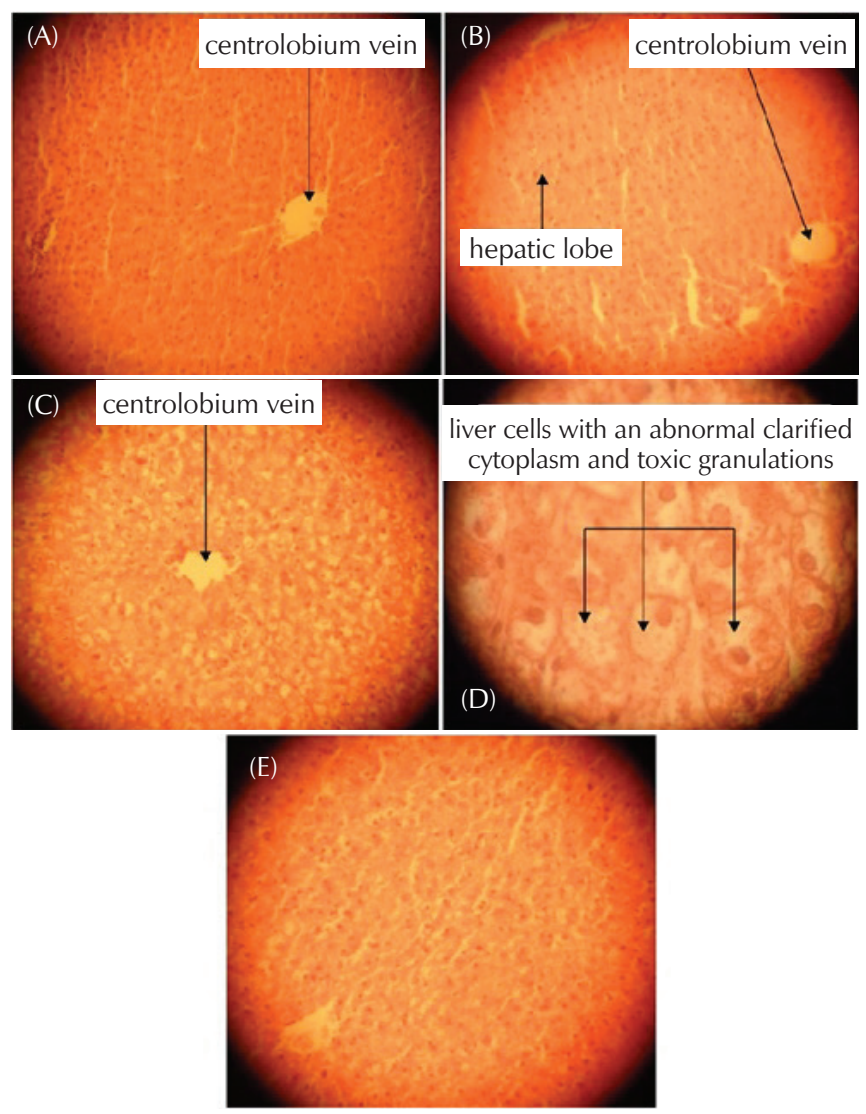

Fig. 4 - (A) Hepatic parenchyma of a healthy histological aspect Lot (1) negative control $(\times 10)$. (B) Hepatic parenchyma of a healthy histological aspect Lot $(2)$ ginger $(\times 10)$. $(C)$ Hepatic parenchyma cell showing an interesting clarification in almost all tissues Lot $(3)$ positive control $(\times 10)$. (D) Hepatic parenchyma cell showing an interesting clarification in almost all tissues Lot (3) positive control $(\times 40)$. (E) Hepatic parenchyma with few clarified cells, Lot (4) cyclohexatriene + ginger (fewer cells with clear cytoplasm) $(\times 10) \cdot{ }^{10}$

\subsubsection{Analysis of Zingiber officinale extract with GC-MS}

The gas chromatography mass spectrum GC-MS, revealed that acetone Zingiber officinale extract contained eight different molecules (Fig. 5), with a characteristic retention time and molecular weight of each molecule (Table 1).

Major constituents of Zingiber officinale extract identified by gas chromatography and mass spectrometry were $\beta$-sesquiphellandrene, curcumene, Zingiberene, and 6 -shogaol.

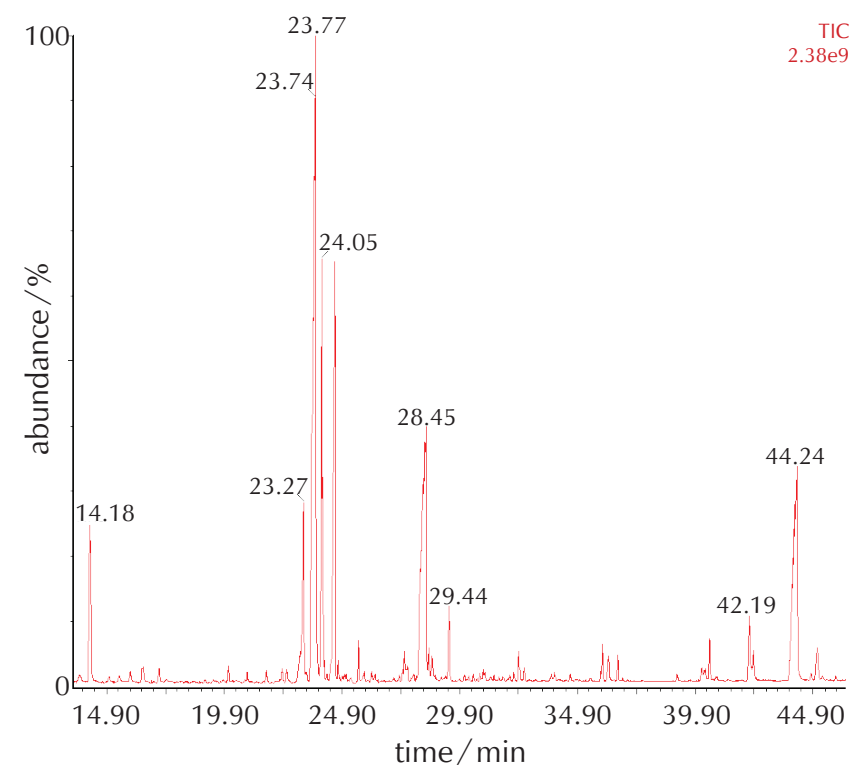

Fig. 5 - GC-MS spectrum of ginger acetone extract

Table 1 - Molecules composing the ginger extract obtained by GC-MS analysis

\begin{tabular}{c|c|c}
\hline Molecule name & $\begin{array}{c}\text { Retention time } \\
/ \mathrm{min}\end{array}$ & $\begin{array}{c}\mathrm{Molecular}^{\mathrm{meight}} \\
/ \mathrm{g} \mathrm{mol}^{-1}\end{array}$ \\
\hline$\beta$-sesquiphellandrene & 17.24 & 204 \\
\hline curcumene & 23.24 & 202 \\
\hline zingiberene & 23.76 & 204 \\
\hline$\alpha$-farnesene & 24.03 & 204 \\
\hline zingerone & 28.36 & 195 \\
\hline 6,10-Dodecadien-1-yn- & 29.43 & 220 \\
\hline -3-ol,3,7,11-trimethyl & 42.15 & 276 \\
\hline $\begin{array}{c}\text { cis-6-Shogaol } \\
\text { trans-6-Shogaol }\end{array}$ & 44.19 & 276 \\
\hline
\end{tabular}

\section{Conclusion}

This investigation reveals that ginger contains a compelling preventive potential against the blood-harmfulness and hepatotoxicity initiated by cyclohexatriene. In addition, as cyclohexatriene fundamentally targets the bone marrow by causing DNA mutations that harm hematopoietic cells, which end up being the wellspring of expansion of cancer-causing cells and the beginning of leukaemia, ginger can protect against leukaemia and against marrow harm instigated by xenobiotic factor. Thus, it is obvious that ginger is a compelling defender against natural factors. The remedial action of ginger against leukaemia should be further investigated.

\section{Conflict of interests}

The corresponding author states that there is no conflict of interest. 


\section{ACKNOWLEDGEMENTS}

The authors would like to thank the staff of the Pharmaceutical Company (SAIDAL) of Médéa (Algeria), and the Laboratory of the Scientific Police of Algiers for their support and for providing the material. We are extremely grateful to Miss Amira Benzaid, Mr. Boualem Benayad, Pr. Oumouna Mustapha, Dr. Benayad Hayet, Miss. Meddahi Saliha, Mr. Hammoudi Mounir, and Mr. Moumen Riadh.

\section{References \\ Literatura}

1. J. Fernando, R. Jones, The principles of cancer treatment by chemotherapy, Surgery (Oxford) 33 (3) (2015) 131-135, doi: https://doi.org/10.1016/j.mpsur.2015.01.005.

2. A. Kapinova, P. Kubatka, O. Golubnitschaja, M. Kello, P. Zubor, P. Solar, M. Pec, Dietary phytochemicals in breast cancer research: anticancer effects and potential utility for effective chemoprevention, Environ. Health Prevent. Med. 23 (2018) 36, https://doi.org/10.1186/s12199-018-0724-1.

3. M. Calvani, A. Pasha, C. Favre, Nutraceutical Boom in Cancer: Inside the Labyrinth of Reactive Oxygen Species, Int. J. Mol. Sci. 21 (6) (2020) 1936, doi: 10.3390/ijms21061936.

4. E. Y. Lee, Y.-J. Surh, Induction of apoptosis in HL-60 cells by pungent vanilloids, [6]-zingiberol and [6]-paradol, Cancer Lett. 134 (1998) 163-168, doi: https://doi.org/10.1016/ S0304-3835(98)00253-5.

5. M.-H. Hsu, S.-C. Kuo, C.-J. Chen, J.-G. Chung, Y.-Y. Lai, L.-J. Huang, 1-(3,4-Dimethoxyphenyl)-3,5-dodecenedione (I6) induces G1 arrestand apoptosis in human promyelocytic leukemia HL-60 cells, Leukem. Res. 29 (2005) 1399-1406, doi: https://doi.org/10.1016/j.leukres.2005.04.014.

6. Q.-Y. Wei, Cytotoxic and apoptotic activities of diarylheptanoids and gingerol-related compounds from the rhizome of
Chinese Zingiber officinale, J. Ethnopharmacol. 102 (2) (2005) 177-184, doi: https://doi.org/10.1016/j.jep.2005.05.043.

7. M. Derelanko, The Toxicologist's Pocket Handbook Second Edition, CRC Press; Taylor \& Francis Group; Library of Congress Cataloguing-in-Publication Data, 2008, p. 12.

8. C. D. Klaassen, Casarett and Doull's Toxicology the Basic Science of Poisons, $7^{\text {th }}$ Ed. by The McGraw-Hill Companies, Inc, 2008, pp. 1007, 1277 .

9. R. Martoja, Initiation aux techniques de l'histologie animale, Masson, Paris, 1967, p. 349.

10. K. Otmanine, K. Oumouna-Benachour, N. Terki, S. Hanini, R. Bekri, K. Amroun, H. Benayed, Study of the preventive potential of Zingiber officinale, against myelotoxicity and against the development of leukemia, induced by benzene, Life Sci. J. 14 (7) (2017) 73-87, doi: https://doi.org/10.7537/ marslsj140717.13.

11. N. Mascolo, R. Jain, S. C. Jain, F. Capasso, Ethnopharmacologic Investigation of Zingiber officinale, J. Ethnopharmacol. 27 (1989) 129-140, doi: https://doi.org/10.1016/03788741(89)90085-8.

12. D. Tucker, M. S. Hamilton, J. P. Kerr, C. Wickham, H. Hunter, Lytic bone disease as the presenting feature of Philadelphia-positive monosomy 7 myelodysplasia progressing to acute myeloid leukaemia, Gene 501 (2) (2012) 219-221, doi: https://doi.org/10.1016/j.gene.2012.04.024.

13. R. C. Lindsley, Mutational complexity in myelodysplasia, Best Pract. Res. Cl. Ha. 30 (4) (2017) 290-294, doi: https://doi. org/10.1016/j.beha.2017.10.003.

14. F. Naeim, P. Nagesh Rao, S. X. Song, Chapter 20 - Acute Myeloid Leukemias with Myelodysplasia-related Changes, Atlas of Hematopathology (2nd Ed.), Academic Press, 2018, pp. 327-333, doi: https://doi.org/10.1016/B978-0-12-8098431.00020-6.

15. Q. Li, Z. Chen, Y. You, P. Zou, Transient pancytopenia preceding acute lymphoblastic leukemia with positive Philadelphia chromosome, Leukem. Res. 32 (8) (2008) 1317-1320, doi: https://doi.org/10.1016/j.leukres.2008.01.006.

\section{SAŽETAK}

\section{Preventivna aktivnost đumbira (Zingiber officinale) u suzbijanju mijelotoksičnosti i hepatotoksičnosti izazvane cikloheksatrienom i identifikacija najaktivnijih spojeva metodom GC-MS

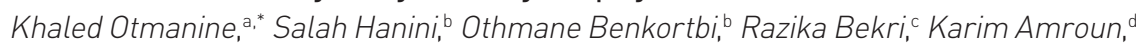 Merouane Djellal, Sara Kohlia i Karine Oumouna-Benachoure}

Cilj ove studije bio je otkriti preventivnu sposobnost Zingiber officinale u suzbijanju mijelotoksičnosti, leukemije i hepatotoksičnosti. Ovaj je rad većim dijelom temeljen na potkožnom ubrizgavanju cikloheksatriena u kuniće da bi se sintetskom strategijom izazvala bolest. Usporedno s time, druga skupina kunića bila je izložena injekciji cikloheksatriena u sličnim uvjetima s hranjenjem Zingiber officinale, gdje je otkriveno da je suprotstavljena mijelotoksičnost izazvana cikloheksatrienom. Histološkim pregledom dodatno je otkriven hepatoprotektivni intenzitet Zingiber officinale. Najviše farmakološki aktivnih molekula Zingiber officinale prepoznato je metodom plinske kromatografije-masene spektrometrije (GC-MS).

Ključne riječi

Zingiber officinale, hepatoprotektivno djelovanje, cikloheksatrien, mijelotoksičnost, GC-MS
Izvorni znanstveni rad Prispjelo 3. rujna 2020. Prihvaćeno 24. listopada 2020.
University of Chlef, Faculty of Technology, Department of Process Engineering, 02000 Chlef, Alžir

${ }^{\mathrm{b}}$ Biomaterials and Transport Phenomena Laboratory (LBMPT),

Yahia Fares University, Médéa, 26 000, Alžir

'Laboratory of Haematology, Mohamed Boudiaf Hospital, Médéa, Alžir

' Laboratory of Pathological Anatomy, Mohamed Boudiaf

Hospital, Médéa, Alžir

'Biomaterials and Transport Phenomena Laboratory (LBMPT),

Médéa, 26 000, Alžir 